\title{
Grażyna Musialik
}

Akademia Techniczno-Humanistyczna w Bielsku-Białej

e-mail: gramusa@wp.pl

\section{KAPITAŁ W EKONOMII I RACHUNKOWOŚCI - POTRZEBA REINTERPRETACJI \\ CAPITAL IN ECONOMICS AND ACCOUNTING - THE NEED FOR REINTERPRETATION}

DOI: $10.15611 /$ pn.2017.488.14

JEL Classification: B12, B14, M41, O34

Streszczenie: W gospodarce przemysłowej głównym, obok pracy, czynnikiem wytwórczym były aktywa kapitałowe. W gospodarce postindustrialnej zasadnicze znaczenie ma włączenie $\mathrm{w}$ proces wytwórczy wiedzy. Wiedza jest zasobem niematerialnym, trudno mierzalnym $\mathrm{i}$ związanym z zespołem ludzi, zatem traktowanie jej jako czynnika wytwórczego należy poprzedzić rozpoznaniem podobieństw i różnic w stosunku do tradycyjnych zasobów, takich jak kapitał i praca. Celem artykułu jest prześledzenie funkcjonowania pojęcia kapitału w ekonomii i rachunkowości i wskazanie na problemy związane z wprowadzeniem do nich pojęcia kapitału intelektualnego. Wskazano na społeczny charakter wiedzy, którą należy traktować jako rezultat kolektywnego i kumulatywnego procesu trwającego przez pokolenia. Traktowanie wiedzy jako dobra publicznego prowadzi do pytań o sprawiedliwy podział wypracowanej wartości dodatkowej związanej z wykorzystywaniem wiedzy w procesie gospodarczym.

Słowa kluczowe: kapitał, czynniki wytwórcze, kapitał intelektualny.

Summary: In the industrial economy the main factors of production were capital and labour. In the post-industrial economy the main factor of production is knowledge. It is difficult to to measure and exhibit a lot of specific properties. It is related to groups of workers, but it cannot.identified with labour There are two goals of this article. Firstly, it aims to describe of the concept of capital in economics and accounting. Secondly, it analyzes the concept of intellectual capital and emphasizes its cumulative and social nature. Interpreting it as a public good leads to the questions about distribution of its benefits, too.

Keywords: capital, factors of production, intellectual capital.

\section{Wstęp}

Współcześnie w krajach wysoko rozwiniętych o przewadze konkurencyjnej w znaczącym stopniu decydują zasoby nie ujęte w bilansach firm, związane z umiejętno- 
ścią gromadzenia, wytwarzania i wykorzystania wiedzy. Przez aktywa wiedzy (nazywane w literaturze aktywami, wartościami bądź kapitałem $\mathrm{z}$ dodaniem przymiotnika intelektualne lub niematerialne) rozumie się, w pewnym uproszczeniu, sumę ukrytych, nie uwzględnianych w bilansie, aktywów mających wpływ na wycenę rynkową przedsiębiorstwa [Dobija 2004]. Obserwowany rozdźwięk pomiędzy wyceną rynkową i wartością księgową, szczególnie firm nowych technologii, skłania do postawienia pytania o obowiązującą w rachunkowości zasadę prawdziwego i rzetelnego obrazu. W sytuacji, kiedy zakres informacji ujawnianej w bilansie przedsiębiorstwa nie zmienia się od wieków, pojawiają się twierdzenia o braku praktycznego zastosowania rachunkowości i kryzysie jej celowości. Przyczynę tego stanu rzeczy można wiązać z paradygmatem tradycyjnej rachunkowości skoncentrowanym wokół pojęcia kapitału [Niemczyk 2013, s. 8]. W naukach ekonomicznych pojęcie kapitału jako jednego z czynników produkcji jest wyraźnie odróżniane od innego co do swej natury czynnika, jakim jest praca. W wypadku kapitału intelektualnego, którego „nośnikiem” jest zespół ludzi zatrudnionych w przedsiębiorstwie, mamy do czynienia ze specyficznym zespoleniem kapitału i pracy. Warto zastanowić się, na ile jest to sytuacja nowa i jak pojęcie kapitału intelektualnego wpisuje się $\mathrm{w}$ tradycję ekonomiczną. Celem opracowania jest przedstawienie ewolucji pojęcia kapitału w ekonomii i rachunkowości i wskazanie na problemy związane $\mathrm{z}$ wprowadzeniem do nich pojęcia kapitału intelektualnego.

\section{Kapitał jako kategoria ekonomiczna}

Pojęcie kapitału jest wieloznaczne i zarówno w przeszłości, jak i dzisiaj wywołuje liczne spory interpretacyjne. Niezaprzeczalnie można stwierdzić, że stało się ono źródłosłowem dla pojęć kapitalista i kapitalizm, określających odpowiednio właściciela kapitału i historycznie ukształtowany system społeczno-gospodarczy, zatem mówiąc o kapitale, trzeba mieć na uwadze także tę semantyczną zależność.

W najbardziej ogólnym ujęciu kapitał określa się jako wartość posiadającą zdolność do samopomnażania, nazywaną w literaturze wartością dodatkową, zyskiem, dywidendą lub procentem, natomiast w praktycznym ujęciu za kapitał uznaje się zasoby służące do procesu produkcji bądź wymiany.

Śledząc historyczną ewolucję pojęcia, można wskazać trzech autorów, w pracach których kapitał ujęty jest w sposób szczególnie nowatorski i odkrywczy, są to: Adam Smith, Karol Marks i Eugene von Bohm-Bawerk.

Smith uznawany za założyciela angielskiej klasycznej szkoły w ekonomii wyróżnił trzy podstawowe elementy uczestniczące w procesie produkcji (czynniki produkcji): pracę ludzką, ziemię i kapitał. Ziemia (w znaczeniu ogółu bogactw naturalnych) i praca to czynniki nie podlegające odtworzeniu. Natomiast kapitał, który jest używany w bieżącym procesie produkcyjnym, jest wynikiem mającego miejsce $\mathrm{w}$ przeszłości jakiegoś innego procesu produkcyjnego i również w przyszłości może być w ten sposób odtwarzany. Zatem główną cechą odróżniającą czynniki kapita- 
łowe od czynników naturalnych jest fakt wytworzenia ich przez człowieka. Tak definiowany kapitał ma formę rzeczową i musi być wyraźnie odróżniany od kapitału finansowego.

Za największy wkład Smitha w rozwój ekonomii jest uznawana jego teoria wartości, gdzie, wyjaśniając zasady rządzące podziałem bogactwa narodowego, wyróżnia trzy rodzaje dochodów pierwotnych: płacę, zysk i rentę. Praca tworzy wartość, która w procesie podziału wartości przyjmuje formę płacy. Wartościotwórcza rola kapitału uzasadnia otrzymywanie przez jego właścicieli dochodu w formie zysku, natomiast właściciele czynników naturalnych mają uzasadnione prawo do wynagrodzenia nazywanego rentą.

Smith duże znaczenie przywiązywał do roli, jaką w tworzeniu bogactwa narodowego i stymulowania rozwoju gospodarczego odgrywa akumulacja kapitału. W swoich pracach wykazał, że podział pracy determinuje akumulację, wpływając w sposób zasadniczy na wielkość globalnego produktu narodowego. Ponadto indywidualny egoistyczny interes wraz z akumulacją kapitału prowadzi według Smitha do optymalnej alokacji kapitału pomiędzy poszczególne gałęzie gospodarki. Akumulacja kapitału wymaga instytucjonalnych ram wolnego rynku i ochrony własności prywatnej, co więcej, do zapewnienia wysokiej stopy akumulacji konieczny jest, dowodził autor, nierówny podział dochodu, ponieważ w przeciwnym razie znaczna część globalnego produktu jest konsumowana.

W rozważaniach Smitha pojawia się pojęcie kapitału ludzkiego definiowanego jako wartość pożytecznych umiejętności nabytych w procesie kształcenia czy terminowania $\mathrm{w}$ jakimś zawodzie. Tak rozumiany kapitał ludzki jest, wraz z budynkami narzędziami i maszynami, zaliczony do kapitału trwałego, czyli według Smitha takiego, który stale uczestniczy w procesie produkcji bez zmiany właściciela. Należy przypuszczać, że wartość dodatkowa związana z zaangażowaniem kapitału ludzkiego jest przejmowana przez właściciela przedsiębiorstwa w formie zysku, a także częściowo przez pracowników wynagradzanych stosownie do posiadanych kwalifikacji [Smith 1954].

Adam Smith miał szeroką filozoficzną wizję społeczeństwa, dostrzegał powiązania pomiędzy wolnością polityczną i gospodarczą oraz między prywatną własnością i sprawiedliwością, a także wskazywał na społecznie pożądaną rolę posiadacza kapitału. Głoszone przez niego poglądy są pochwałą systemu społeczno-gospodarczego opartego na prywatnej własności, wolności osobistej i swobodzie zawierania umów. Kształtowanie systemu stosunków społecznych opartego na powyższych wartościach było procesem historycznym, który podlegał ewolucji i zmianie. Karol Marks jako jego cechę konstytutywną wskazał prywatną własność środków produkcji (kapitału) skupioną w rękach relatywnie nielicznej grupy osób (klasy kapitalistów) i użył na jego określenie nazwy kapitalizm.

Myśl Marksa jest kombinacją heglizmu, idei francuskich utopistów i klasycznej ekonomii. Marks był przede wszystkim filozofem, a swoje życiowe zadanie, zgodnie z naukami swojego mistrza Hegla, widział nie tylko w interpretowaniu i anali- 
zowaniu rzeczywistości, lecz przede wszystkim w jej zmienianiu. W jego pracach prowadzona jest jednocześnie analiza filozoficzna, socjologiczna i ekonomiczna. Wyodrębnienie z tego splotu teorii czysto ekonomicznej było bardzo trudne, choć ważne ze względu na odkrywczość i nowatorstwo Marksa w podejściu do zagadnień ekonomicznych. Ekonomiści klasyczni skupiali uwagę na statycznej równowadze gospodarki, gdy tymczasem Marksa interesował dynamiczny proces zmian, a celem jego prac było odkrycie praw rządzących dynamiką kapitalizmu. W warstwie ekonomicznej prace Marksa są, przeprowadzoną z użyciem nowych kategorii pojęciowych, nowatorską analizą kapitalizmu. Oskar Lange twierdził, że ekonomia ortodoksyjna i marksizm to dwa nurty nawzajem się uzupełniające, i co więcej, że zrozumienie ewolucyjnego charakteru kapitalizmu możliwe jest tylko w ramach kategorii marksowskich [Lange 1975 (tom III), s. 21-22].

Przed Marksem termin kapitał był używany w odniesieniu do zasobu dóbr (ewentualnie pieniądza) wykorzystywanych w procesie wytwórczym. Zakres pojęciowy terminu używanego przez Marksa jest inny: kapitał nie jest rzeczą, lecz określonym stosunkiem produkcyjnym, należącym do określonej historycznie formacji, który wyraża się w rzeczy i rzeczy tej nadaje specyficzny charakter społeczny. Kapitał zatem jest szczególnym stosunkiem społecznym, łączącym klasę posiadaczy środków produkcji (kapitalistów) z klasą robotniczą. Zaprezentowana w pierwszym tomie jego Kapitatu teoria wartości dodatkowej jest motywem przewodnim marksistowskiej ekonomii, w której Marks dowodzi, że zysk przypadający właścicielowi kapitału jest wartością dodatkową wytworzoną przez pracę, z czego należy wyciągać wnioski natury etycznej [Blaug 1994].

Na podstawie krytycznej analizy kapitalizmu i sformułowanych „,praw ruchu” Marks przedstawił wizję ewolucji systemu, z których niewielka część okazała się prorocza. Przewidywaną przez niego konsekwencją postępującej koncentracji i centralizacji kapitału jest monopolizacja coraz większych obszarów gospodarki i oddzielenie własności od zarządzania. Proces centralizacji Marks wiąże z rozwojem systemu kredytowego i korporacyjnej formy organizacji przedsiębiorstw.

Ten wątek w pracach Marksa podjęty został przez Rudolfa Hilferdinga, który twierdził, że oprócz kapitału przemysłowego istnieje także kapitał kredytowy, a w jego ramach kapitał bankowy. Organizowanie przedsiębiorstw w formie spółek akcyjnych spowodowało, z jednej strony, scalenie kapitału przemysłowego i bankowego w jednolity kapitał finansowy, a z drugiej strony oddzielenie własności kapitału od funkcji kierowania przedsiębiorstwem. Według Hilferdinga są to wyróżniki kolejnego stadium kapitalizmu.

Ostatnie trzydziestolecie wieku XIX to okres wprowadzania w teoriach ekonomicznych nowych narzędzi analitycznych z analizą marginalną na czele. W tym samym czasie powstają trzy szkoły myśli ekonomicznej, stosujące podobne podejście metodologiczne: szkoła austriacka, szkoła lozańska oraz szkoła anglo-amerykańska. Z punktu widzenia wkładu w rozwój teorii kapitału najważniejszą rolę odegrała szkoła austriacka, a szczególnie prace Eugene von Bohm-Bawerka i Irvinga Fishera. 
W ekonomii klasycznej dochód z kapitału nazywano zyskiem, przy czym pojęcie to obejmowało to, co w dzisiejszej terminologii nazywa się zarówno zyskami, jak i procentem. Brak u klasyków powyższego rozróżnienia jest zrozumiały, ponieważ w czasach rodzącego się kapitalizmu w typowych przedsiębiorstwach nie występował rozdział funkcji dostawcy funduszy i menedżera. Jednak już w klasycznych pracach dochód kapitalisty rozdzielany jest na trzy elementy: zapłata za użytkowanie kapitału (według współczesnej klasyfikacji podpada pod pojęcie procentu), zapłata dla przedsiębiorcy za oddane usługi menedżerskie oraz zapłata z tytułu ponoszonego ryzyka. Rozwój korporacyjnej formy prowadzenia działalności gospodarczej i związane z tym rozdzielenie własności i zarządzania ujawniły niedostatki klasycznych teorii kapitału. Wkład w przedsiębiorstwo w postaci usług menedżerskich i ponoszonego ryzyka zaczęto identyfikować z czwartym czynnikiem wytwórczym nazywanym przedsiębiorczością, co jednak rodziło kolejne komplikacje i uznane zostało za rozwiązanie niezadowalające.

Historycznie rzecz biorąc, największe znaczenie w rozwoju teorii procentu miały prace Bohm-Bawerka, według którego istnieją tylko dwa pierwotne czynniki produkcji - ziemia i praca, natomiast kapitał jest czynnikiem pochodnym, który wiąże czynniki elementarne i umożliwia realizację rozciągających się w czasie procesów produkcyjnych. Główną zasługą Bohm-Bawerka jest właśnie zwrócenie uwagi na znaczenie takiego elementu jak czas (czekanie) w działalności gospodarczej, który przez część kontynuatorów był traktowany jako kolejny, obok ziemi i pracy, pierwotny czynnik produkcji. Za fundamentalną przyczynę istnienia procentu Bohm-Bawerk uważał to, że obecne dobra są wyżej cenione (więcej warte) niż taka sama ilość dóbr przyszłych, a jako powód takiego wartościowania wskazał przyczyny psychologiczne - słabość wyobraźni i skończoność życia.

Irving Fisher podjął odkrywcze idee Bohm-Bawerka, lecz zaproponował zupełnie nowe spojrzenie na problem, wychodząc od filozoficznej analizy charakteru kapitału i przyczyn istnienia procentu. Bohm-Bawerk był wierny tradycji rozróżniającej poszczególne czynniki produkcji i przychody im przypadające, zatem jego teoria z konieczności ujmowała procent w odróżnieniu od płacy i renty. Nowatorskie podejście Fishera do omawianych problemów polegało na potraktowaniu procentu jako sposobu analizy wszelkich strumieni dochodu (także płacy i renty). Przepływy dochodów z poszczególnych czynników produkcji dokonują się w czasie, więc aby ustalić przychód procentowy z danego czynnika, trzeba porównać jego cenę z wartością skapitalizowanego według bieżącej stopy procentowej strumienia przepływów, związanego z tym czynnikiem. Zatem renta, płaca i procent to różne sposoby mierzenia tego samego co do swej natury dochodu. Stopa procentowa, według Fishera i jego kontynuatorów, jest miarą ceny, jaką ludzie gotowi są płacić za uzyskanie dochodu dzisiaj, a nie dopiero w przyszłości. Cenę tę określają dwa rodzaje przyczyn: subiektywne - odzwierciedlające preferencje jednostek, oraz obiektywne - zależne od możliwości inwestycyjnych [Fisher 1954]. 
Szkoła austriacka definiuje kapitał, wiążąc go z kategorią czasu, co jest podejściem zasadniczo odmiennym w stosunku do ujęcia klasycznego. Takie podejście ma daleko idące konsekwencje $\mathrm{w}$ teoriach makroekonomicznych, co uwidoczniło się w pracach przedstawicieli monetaryzmu czerpiących z tradycji szkoły austriackiej.

We współczesnych naukach ekonomicznych pojęcie kapitału używane jest zarówno w mikroekonomii, w odniesieniu do przedsiębiorstwa, jak i w makroekonomii, w odniesieniu do gospodarki narodowej jako całości, między innymi w teorii podziału, teorii koniunktury i teorii wzrostu gospodarczego.

Powyższe zestawienie koncepcji kapitału ma charakter subiektywny i nie wyczerpuje problematyki związanej z identyfikacją, definiowaniem i pomiarem kapitału w ekonomii. Zestawienie koncepcji Smitha, Marksa i szkoły austriackiej jako swego rodzaju „kroków milowych” w ekonomii miało na celu wskazanie powiązań pomiędzy przyjmowaną koncepcją kapitału, prawem własności, prawem do osiąganych korzyści i społecznymi konsekwencjami głoszonych teorii.

\section{Kapitały w interpretacji rachunkowości}

Rachunkowość jest nauką w specyficzny, właściwy tylko dla niej, sposób ujmującą rzeczywistość gospodarczą. Zatem sposób definiowania i wyceny kapitałów we współczesnej praktyce rachunkowości trzeba rozpatrywać na szerszym tle teorii rachunkowości, a zwłaszcza jej metodologii. Rachunkowość jako działalność praktyczna istniała od stuleci i rozwijała się wraz z postępem technologicznym i organizacyjnym, jednak o namyśle teoretycznym, czyniącym z rachunkowości dyscyplinę naukową, można mówić dopiero od przełomu XIX i XX wieku. Rachunkowość jest zaliczana obecnie do stosowanych nauk społecznych, co oznacza, że jest nauką ze względu na jej metodę, a nauką stosowaną ze względu na jej zorientowanie na cel. Celem tym jest dostarczanie informacji użytkownikom, którzy wykorzystują je między innymi na potrzeby zarządcze, kontrolne, analityczne i planistyczne. Rachunkowość zatem jest systemem informacyjnym mającym ułatwiać podejmowanie decyzji gospodarczych, zwłaszcza finansowych, a także pozwalającym na dokonanie oceny efektywności zarządzania majątkiem przedsiębiorstwa.

W literaturze przedmiotu panuje zasadniczo zgoda co do podmiotu rachunkowości (jednostki gospodarujące cechujące się majątkowym wyodrębnieniem) i jej przedmiotu (procesy gospodarcze i zaangażowane w nich zasoby), natomiast jeżeli chodzi o metodologię rachunkowości, dyskusja jest otwarta.

J. Górski odnosił pojęcie metody do specyficznego sposobu myślowego postrzegania i rozpatrywania przedmiotu rachunkowości. Metoda w takim ujęciu nie jest sposobem działania, lecz procesem myślowym, w którym Górski wyróżnia dopełniające się nawzajem elementy: metodę podmiotową, metodę momentów i okresów sprawozdawczych, metodę grupowania, metodę wyceny i metodę bilansową. Tak wyróżnione metody poznawcze wyczerpują według autora całość specyficznych procesów myślowych, za pomocą których można rozwiązać dowolny problem 
z zakresu tak praktyki, jak i teorii rachunkowości. Istotą wyróżnionych procesów jest bowiem ich obiektywny charakter, niezmienność i ponadczasowość, natomiast zmiany techniczne zachodzące $\mathrm{w}$ gospodarce wpływają jedynie na sprawniejszą realizację wskazanych metod, nie na ich treść [Górski 1975, s. 48-66].

Wśród wyróżnionych sposobów rozumowania szczególne znaczenie dla ujęcia istoty rachunkowości ma metoda bilansowa. Źródłosłów omawianego terminu wskazuje na taki typ rozumowania i wnioskowania, który charakteryzuje się podwójnym podejściem do badanej rzeczywistości. Specyfika metody bilansowej polega na poszukiwaniu i ustalaniu tożsamości - inaczej rzecz ujmując, na ustalaniu równowagi między ilościowymi cechami obserwowanych przedmiotów i zjawisk. Metoda bilansowa polega na ujęciu wybranego pola obserwacji zjawisk ekonomicznych za pomocą równości, która jest zestawieniem dwóch szeregów określonych wielkości ekonomicznych, charakteryzujących opisywany wycinek rzeczywistości ekonomicznej z dwóch różnych stron. Zastosowanie metody bilansowej w rachunkowości polega na ujmowaniu majątku podmiotu (w znaczeniu: zasoby niezbędne do prowadzenia działalności gospodarczej), a także zdarzeń i procesów gospodarczych w dwóch różnych, równoważących się kwotowo aspektach. Metoda bilansowa narzuca specyficzny, podwójny sposób obserwacji i interpretacji podmiotu gospodarczego. Dwuaspektowe ujęcie polega na określeniu z jednej strony struktury posiadanych przez jednostkę zasobów w aspekcie rzeczowym, a z drugiej na określeniu struktury źródeł finansowania tychże zasobów (aspekt finansowy).

Kategoria kapitałów (funduszy) stosowana w rachunkowości jest wynikiem podejścia do posiadanych przez jednostkę zasobów w aspekcie finansowym z uwzględnieniem praw własności podmiotów będących źródłami finansowania. Kapitały (fundusze) są zatem stosunkami prawnymi, w przeciwieństwie do składników majątkowych, które występują jako rzeczy lub jako prawa do korzystania $\mathrm{z}$ rzeczy.

Podstawowy podział kapitałów (funduszy) jednostek gospodarczych dokonywany jest ze względu na charakter prawa własności i zgodnie z tym wyróżnia się kapitały (fundusze) własne i kapitały (fundusze) obce. Termin prawo własności (equity) $\mathrm{w}$ języku angielskim nawiązuje znaczeniem do terminu równy i sprawiedliwy (equal) [Henderson, von Breda 2002]. Termin kapitał, traktowany jako tożsamy z prawem własności i stosowany zgodnie z metodą bilansową, implikuje wskazanie jako zasadniczego równania rachunkowości formuły:

\section{AKTYWA (assets) $=$ KAPITAŁY (equities).}

Zaznaczyć trzeba, że nie jest to jedyne możliwe podejście do zagadnienia należnego udziału w przedsiębiorstwie i termin kapitał stosowany jest przez część autorów w węższym sensie, w odniesieniu wyłącznie do kapitału własnego, ponieważ jedynie z nim wiążą oni należne prawa własności. 
Uznaje się za celowe rozwijanie rachunkowości kapitału intelektualnego i wypracowanie metod ewidencyjnych pozwalających na rejestrowanie zasobów wiedzy kontrolowanych przez przedsiębiorstwo. Wprawdzie istnieją uzasadnione obawy, że włączenie do bilansu pozycji trudno mierzalnych w sposób nieadekwatny odda rzeczywistą ich wartość, lecz z drugiej strony ich nieuwzględnianie powoduje niską użyteczność informacyjną sprawozdań finansowych [Jarugowa, Fijałkowska 2002]. Zatem identyfikacja, pomiar i rejestracja wszystkich zasobów, którymi dysponuje przedsiębiorstwo, wraz ze wskazaniem źródeł ich pochodzenia, jest ważnym kierunkiem badań.

\section{Kapital w gospodarce postindustrialnej}

W gospodarce przemysłowej głównym, obok pracy, czynnikiem wytwórczym były aktywa kapitałowe. Świadomość, iż o przewadze konkurencyjnej oprócz wspomnianych zasobów decyduje także sposób ich zorganizowania i zarządzania nimi, była powszechna, a w każdym razie stała się taka od czasu rozwoju nauk o zarządzaniu. Zatem pewien rodzaj wiedzy organizacyjnej był niejako „nadbudowanym” nad kapitałem i zasobami pracy czynnikiem generującym dodatkowy zysk dla właściciela przedsiębiorstwa. Analiza natury tak rozpoznanego czynnika prowadzi do pytań, na ile wzmiankowana wiedza jest oderwana od ludzi pracujących w przedsiębiorstwie i w jakiej mierze generowana przez nią dodatkowa wartość jest należna właścicielowi kapitału. Bezdyskusyjnie przedsiębiorstwo funkcjonuje w pewnym otoczeniu polityczno-społecznym, co wpływa na osiągane zyski, a formą odpłaty na rzecz społeczeństwa są płacone podatki. W liberalnej demokracji przyjmowano, że kapitalista godziwie (to znaczy według rynkowych stawek) wynagradzający pracowników i uczciwie płacący podatki ma prawo cieszyć się osiąganymi zyskami jako dobry obywatel, który dodatkowo stworzył miejsca pracy. Ta narracja załamała się po ostatnim kryzysie finansowym, kiedy, skrótowo rzecz ujmując, okazało się, że zyski są prywatyzowane, a straty nacjonalizowane.

Koniec kapitalizmu jako systemu gospodarczo-społecznego wieszczono wielokrotnie, poczynając od marksistów przekonanych o nieuchronności rewolucji. Pod koniec ubiegłego wieku swoją koncepcję nowego ładu gospodarczego przedstawił Peter Drucker. Punktem wyjścia dla niego jest stwierdzenie, że nie kapitał, nie praca i nie bogactwa naturalne są najważniejszymi (rozstrzygającymi) czynnikami produkcji, lecz najważniejszym obecnie zasobem jest wiedza. Nieobowiązujący, według autora, staje się podział na klasę kapitalistów i klasę robotników. Rolę kapitalistów przejmie według Druckera klasa wysoko wykwalifikowanych pracowników, którzy będą tworzyć wartość dodaną przez zastosowanie w pracy wiedzy [Drucker 1999].

Faktem niepodważalnym jest przyspieszenie rozwoju technologicznego, szczególnie po upowszechnieniu elektronicznego przesyłu informacji. Ze względu na znaczenie przemysłu nowych technologii, w którym wiedza odgrywa podstawową 
rolę, można mówić o gospodarce opartej na wiedzy. Na pewno jednak specjaliści nie zdominowali kapitalistów i mrzonką wydaje się ewolucyjne przejście do nowego porządku społecznego, tak jak chciał tego Drucker. Należy podkreślić, że Drucker, podobnie jak Marks, widzi powiązanie pomiędzy dysponentami nowego czynnika wytwórczego i powstaniem nowej struktury społecznej.

W literaturze ekonomicznej, szczególnie w teoriach kapitału ludzkiego, kapitału społecznego i kapitału intelektualnego, podejmowano problem identyfikowania szeroko rozumianej wiedzy. W zarządzaniu najogólniejsza definicja wiedzy jako ogółu wiadomości i umiejętności wykorzystywanych do rozwiązywania problemów, jest rozszerzana przez wskazanie na proces uczenia się, studiowania i nabywania doświadczenia. W socjologii wiedza i aktywność poznawcza człowieka są traktowane jako rezultat kolektywnego i kumulatywnego procesu trwającego przez pokolenia i wskazuje się na społeczny ich charakter [Białynicki-Birula 2014].

Traktowanie wiedzy jako podstawowego zasobu w gospodarce postindustrialnej wymaga rozpoznania podobieństw i różnic $\mathrm{w}$ stosunku do tradycyjnych zasobów, takich jak kapitał i praca, oraz należnych (adekwatnych, sprawiedliwych, godziwych) udziałów w wypracowanej wartości dodatkowej, w analogii do zysku właściciela i wynagrodzenia pracownika. W rachunkowości, uwzględniającej po stronie aktywów zasoby wiedzy, zgodnie z metodą bilansową, po stronie pasywów należałoby szukać ich „dostawcy”, pamiętając, że w rachunkowości kapitały (fundusze) są stosunkami prawnymi, z którymi związane są odpowiednie prawa.

Wychodząc od najbardziej ogólnej definicji kapitału jako wartości posiadającej zdolność do pomnażania, należy uznać, że wiedza jest w takim sensie kapitałem. $Z$ jednej strony jest to kapitał jednostki ujawniający się jako jej wysokie kwalifikacje, $z$ drugiej strony kapitał intelektualny w przedsiębiorstwie jest większy niż suma wnoszonych przez pracowników kapitałów indywidualnych ze względu choćby na efekt synergii. Czy jednak jest to argument przesądzający o uznaniu wartości dodanej wynikającej z zastosowania wiedzy za należną właścicielowi przedsiębiorstwa? Wąskie rozumienie wiedzy jako elementu składowego kompetencji pracownika pozwala wiązać wiedzę z pracą, a zatem wartość dodatkową z niej wynikającą $\mathrm{z}$ wynagrodzeniem. Jednak wiedza, nawet tak wąsko rozumiana, nie pojawia się w próżni społecznej. Gospodarka oparta na wiedzy jest związana z określonym momentem historycznym wyznaczonym przez rozwój cywilizacyjny, społeczny i polityczny, a także, choć nie przede wszystkim, gospodarczy. Łatwo możemy sobie to uświadomić, rozpoznając bariery wprowadzenia gospodarki opartej na wiedzy w krajach słabo rozwiniętych. Prowadzi to do twierdzenia, że wiedza jest dobrem publicznym i wartość dodatkowa wynikająca z wykorzystania tego zasobu też powinna mieć, chociaż częściowo, charakter publiczny. 


\section{Literatura}

Białynicki-Birula P., 2014, Społeczny kontekst poznania i wiedzy, Zarządzanie Publiczne, nr 2(28).

Blaug M., 1994, Teoria ekonomii, PWN Warszawa.

Dobija D., 2004, Pomiar i sprawozdawczość kapitału intelektualnego w organizacjach działajacych $w$,,nowej gospodarce”, Organizacja i Kierowanie, nr 1, s. 61-76.

Drucker P., 1999, Społeczeństwo pokapitalistyczne, PWN, Warszawa.

Fisher I., 1954, The Theory of Interest, Kelly and Millman, New York.

Górski J., 1975, Metody poznawcze rachunkowości, PWE, Warszawa.

Henderson E.A., von Breda M.F., 2002, Teoria rachunkowości, PWN, Warszawa.

Jarugowa A. Fijałkowska J., 2002, Rachunkowość i zarzadzanie kapitałem intelektualnym. Koncepcje i praktyka, ODDK, Gdańsk.

Lange O., 1975, Ekonomia marksowska a wspótczesna teoria ekonomii, PWN, Warszawa.

Niemczyk L., 2013, Rachunkowość finansowa aktywów kompetencyjnych i kapitatu intelektualnego, Pacioli Institute, Rzeszów.

Smith A., 1954, Badania nad natura i przyczynami bogactwa narodów, PWN, Warszawa. 